\title{
Hubungan antara Adiksi Telepon Pintar dengan Refleks Berkedip dan Kuantitas Air Mata
}

\author{
Salma Tania ${ }^{1}$, Nurfitri Bustamam¹, Winda Lestari² \\ ${ }^{1}$ Fakultas Kedokteran, Universitas Pembangunan Nasional Veteran, Jakarta, Indonesia \\ ${ }^{2}$ Fakultas Kedokteran, Universitas Gunadarma, Depok, Indonesia \\ Alamat Korespondensi: nurfitri.bustamam@upnvj.ac.id
}

\begin{abstract}
Abstrak
Adiksi telpon pintar meningkatkan paparan blue light yang bersifat merusak kornea dan lapisan air mata sehingga dapat mempengaruhi refleks berkedip dan sekresi air mata. Penelitian ini bertujuan untuk mengetahui hubungan antara adiksi telepon pintar dengan refleks berkedip dan kuantitas air mata pada mahasiswa Fakultas Kedokteran Universitas Pembangunan Nasional Veteran Jakarta. Penelitian menggunakan desain potong lintang. Sebanyak 88 subjek dengan kriteria menggunakan telpon pintar, tidak memakai softlens dan obat tetes mata serta tidak memiliki riwayat operasi mata, alergi mata, dan Sindroma Sjorgen, ditentukan menggunakan teknik simple random sampling. Data diambil menggunakan kuesioner smartphone addiction scale, rekaman video, dan Schirmer I Test. Hasil penelitian didapatkan subjek berusia 20 (18-23) tahun, 76,1\% perempuan dan 45,5\% menggunakan telpon pintar lebih dari 6 jam sehari. Sebanyak 52,3\% subjek mempunyai adiksi telepon pintar dengan frekuensi refleks berkedip 11 (3-32) kali/menit dan kuantitas air mata 30,5 (4-35) mm dalam 5 menit. Hasil uji Mann-Whitney menunjukkan tidak ada hubungan antara adiksi telepon pintar dengan refleks berkedip $(\mathrm{p}=0,537)$, tetapi ada hubungan antara adiksi telepon pintar dengan kuantitas air mata $(\mathrm{p}=$ $0,011)$.
\end{abstract}

Kata Kunci: Adiksi telepon pintar, kuantitas air mata, mahasiswa kedokteran, refleks berkedip

\section{The Relationship between Smartphone Addiction with Blink Reflex and Tear Quantity}

\begin{abstract}
Smartphone addiction increases exposure to blue light that can damage the cornea and tear film. This damage can affect the blink reflex and tear secretion. This study aimed to determine the relationship between smartphone addiction and blink reflex and tear quantity. This study used a cross-sectional design with subjects were medical students of Universitas Pembangunan Nasional Veteran Jakarta. A total of 88 subjects were determined using a simple random sampling technique, with the criteria of using smartphones, not wearing contact lenses and eye drops, not having a history of eye surgery, eye allergies, and Sjögren's syndrome. Data were taken using the Smartphone Addiction Scale questionnaire, video recordings, and the Schirmer I test. The study results showed that the subjects aged 20 (18-23) years, $76.1 \%$ female, and $45.5 \%$ using smartphones more than 6 hours a day. As many as $52.3 \%$ of the subjects had a smartphone addiction with blink reflex frequency 11 (3-32) times /minute and tear quantity 30,5 (4-35) millimeters in 5 minutes. Mann-Whitney test results showed no relationship between smartphone addiction with blink reflex $(p=0.537)$, but there was a relationship between smartphone addiction with tear quantity $(p=0.011)$.
\end{abstract}

Keywords: Blink Reflex, Medical Student, Smartphone Addiction, Tear Quantity

\section{Pendahuluan}

Mata merupakan organ sensorik yang menyampaikan $80 \%$ informasi dari lingkungan sekitar. ${ }^{1}$ Fungsi mata dapat dianalogikan serupa How to Cite :

Tania, S., Bustamam, N., Lestari, W. Hubungan antara Adiksi Telepon Pintar dengan Refleks Berkedip dan Kuantitas Air Mata. J Kdokt Meditek. 28(1), 1-7. Available from: http://ejournal.ukrida.ac.id/ojs/index.php/Meditek/article/view/2278/version/2256 DOI:

https://doi.org/10.36452/jkdoktmeditek.v28i1.2278 
Beberapa mekanisme membantu melindungi mata dari cedera, salah satunya adalah korneal refleks yang terdiri dari refleks berkedip dan pengeluaran air mata. ${ }^{4,5}$ Refleks berkedip merupakan refleks penutupan permukaan mata oleh palpebra yang melindungi mata dari keadaan yang mengancam, misalnya benda yang mendekat secara cepat, cahaya yang menyilaukan, dan pada saat bulu mata atau bagian permukaan mata tersentuh. ${ }^{3}$ Refleks berkedip dipengaruhi oleh beberapa keadaan emosional, aktivitas mental misalnya percakapan, penggunaan perangkat digital, dan aktivitas membaca. ${ }^{6}$ Refleks berkedip sangat berperan dalam mekanisme pengeluaran air mata untuk menjaga homeostasis lapisan permukaan mata. Berkedip akan memicu kerja pompa kelenjar lakrimal utama dan akseoris sehingga menyekresikan komponen air mata serta membantu mendistribusikan komponen air mata tersebut ke seluruh permukaan mata. Beberapa penelitian menunjukkan bahwa refleks berkedip normal membantu menjaga keseimbangan lapisan air mata pada permukaan mata. Refleks berkedip erat kaitannya dengan keadaan air mata.,8

Telepon pintar atau smartphone adalah suatu teknologi telepon genggam yang memiliki kemampuan seperti atau lebih canggih dari komputer. Data KOMINFO Tahun 2015 menunjukkan Indonesia adalah negara pengguna telepon pintar terbanyak ke-4 setelah China, India, dan Amerika. Data Pew Research menunjukkan pengguna telepon pintar terbanyak di Indonesia berusia antara 18-34 tahun. Penggunaan telepon pintar dalam jangka waktu lama dapat mengakibatkan adiksi yang merupakan tipe kebiasaan yang tidak terkontrol dan tidak sehat. ${ }^{9,10}$ Mahasiswa diketahui paling banyak mengalami adiksi telepon pintar berdasarkan hasil penelitian di Saudi Arabia dan di China. ${ }^{11,12}$

Sejumlah penelitian mengindikasikan bahwa penggunaan telpon pintar secara berlebihan dan tidak terkendali atau adiksi dapat mengakibatkan gangguan tidur, gangguan bekerja, depresi, kecemasan, kesepian, perilaku berbahaya seperti halnya menggunakan telepon saat mengemudi dan gejala patologis lainnya. ${ }^{13,14}$

Penggunaan telepon pintar lebih dari dua jam dapat meningkatkan risiko ketidaknyamanan pada mata sebanyak dua kali dan menurunkan frekuensi refleks berkedip hingga setengah dari nilai normal, yaitu $15 \mathrm{kali} / \mathrm{menit}^{15,16}$ Paparan cahaya biru dari telepon pintar yang digunakan lebih dari 1 jam akan meningkatkan jumlah reactive oxygen species (ROS) yang menginduksi apoptosis dan nekrosis pada kornea dan lapisan air mata. Selanjutnya gangguan pada permukaan mata terutama kornea akan mengakibatkan gangguan refleks kornea berupa refleks berkedip dan mempengaruhi sekresi air mata. ${ }^{17,18}$

Berdasarkan rasional tersebut, peneliti tertarik untuk mengetahui hubungan antara adiksi telepon pintar dengan refleks berkedip dan kuantitas air mata pada mahasiswa Fakultas Kedokteran Universitas Pembangunan Nasional Veteran Jakarta (FKUPNVJ).

\section{Metodologi}

Penelitian ini merupakan penelitian analitik observasional dengan desain cross sectional. Populasi penelitian ini adalah seluruh mahasiswa aktif FKUPNVJ Tahun Akademik 2019/2020. Kriteria inklusi adalah mahasiswa aktif FKUPNVJ yang memiliki telepon pintar dan bersedia menjadi subjek penelitian. Mahasiswa yang menggunakan softlens, menggunakan obat tetes mata yang mengandung benzalkonium klorida, memiliki riwayat operasi mata minimal satu tahun sebelumnya seperti Lasik, memiliki riwayat alergi pada bagian mata, dan mengalami penyakit sindroma Sjorgen yang mengakibatkan sindroma mata kering dieksklusi dari penelitian.

Besar sampel ditentukan dengan rumus beda proporsi dengan $\alpha=5 \%, \beta=80 \%, \mathrm{P}_{1}=0,73$ dan $\mathrm{P}_{2}=0,4$ yang diambil dari penelitian tentang adiksi telpon pintar dan mata kering. ${ }^{19}$ Hasil perhitungan didapatkan 80 orang. Selanjutnya hasil perhitungan ditambah $10 \%$ untuk mengantisipasi kemungkinan drop out, sehingga didapatkan besar sampel 88 orang.

Setelah mendapatkan ethical clearance dari Komisi Etik Penelitian Kesehatan Universitas Pembangunan Nasional Veteran Jakarta (Surat Nomor: B/2430/III/2020/KEPK), penelitian dilaksanakan di FKUPNVJ pada bulan Maret 2020. Kuesioner untuk menjaring subjek dibagikan kepada 125 mahasiswa dan didapatkan 109 orang yang sesuai kriteria penelitian. Selanjutnya dipilih 88 subjek dari 109 orang tersebut dengan teknik simple random sampling menggunakan program Microsoft Excel. Data penelitian dianalisis menggunakan SPSS versi 17.

Subjek yang terpilih diminta untuk mengisi kuesioner data demografi dan data penggunaan telpon pintar, kemudian mengisi kuesioner smartphone addiction scale ${ }^{14}$ untuk mengetahui apakah subjek memiliki kecanduan terhadap telpon pintar. Kuesioner smartphone addiction scale yang digunakan adalah versi bahasa Indonesia yang 
telah diuji validitasnya pada populasi penelitian ini dan didapatkan Cronbach Alpha $=0,938$.

Selanjutnya subjek diminta duduk dan menatap ke arah kamera video untuk direkam refleks berkedipnya selama tiga menit. Rekaman video tersebut digunakan sebagai alat ukur untuk menghitung jumlah refleks berkedip setiap menit dengan menggunakan aplikasi windows media player dengan perlambatan 25 gambar/detik. Frekuensi berkedip pada menit pertama tidak dihitung, karena merupakan waktu penyesuaian subjek. Kuantitas air mata subjek diukur menggunakan metode Schirmer test I tanpa menggunakan anastesi topikal dengan tujuan untuk mengukur sekresi air mata basal. Kertas Schirmer diletakkan di palpebra inferior sepertiga temporal membentuk sudut 90 derajat dengan mata tertutup selama 5 menit. Banyaknya air mata yang membasahi kertas Schirmer diukur dalam satuan milimeter.
Analisis univariat digunakan untuk mengetahui distribusi, frekuensi, dan persentase dari setiap variabel yang diteliti. Selanjutnya dilakukan analisis menggunakan uji MannWhitney untuk mengetahui hubungan antara adiksi telepon pintar dengan frekuensi refleks berkedip dan kuantitas air mata.

\section{Hasil}

Hasil penelitian didapatkan subjek berusia 20 (18-23) tahun, 76,1\% berjenis kelamin perempuan, 45,5\% menggunakan telpon pintar lebih dari 6 jam setiap hari, 43,2\% menggunakannya dengan frekuensi 21 - 50 kali per-hari, dan 33,3\% subjek menggunakannya untuk aktivitas sosial media. Sebanyak 37,5\% subjek mengetahui efek blue light pada mata, tetapi $62,5 \%$ subjek tidak menggunakan filter blue light pada telepon pintarnya (Tabel 1).

Tabel 1. Karakteristik Subjek Penelitian

\begin{tabular}{|c|c|c|}
\hline Karakteristik & $\begin{array}{c}\text { Frekuensi } \\
\text { (n) }\end{array}$ & $\begin{array}{c}\text { Persentase } \\
(\%)\end{array}$ \\
\hline \multicolumn{3}{|l|}{ Jenis Kelamin } \\
\hline Laki - laki & 21 & 23,9 \\
\hline Perempuan & 67 & 76,1 \\
\hline Usia & \multicolumn{2}{|c|}{ Median (Minimum-Maksimum) } \\
\hline \multicolumn{3}{|l|}{ Durasi Penggunaan Telepon Pintar } \\
\hline 11-60 menit/hari & 4 & 4,5 \\
\hline $1-3 \mathrm{jam} / \mathrm{hari}$ & 8 & 9,1 \\
\hline $3-6$ jam/hari & 36 & 40,9 \\
\hline$>6 \mathrm{jam} / \mathrm{hari}$ & 40 & 45,5 \\
\hline \multicolumn{3}{|l|}{ Penggunaan } \\
\hline$<5 \mathrm{x}$ sehari & 1 & 1,1 \\
\hline 6-10x sehari & 15 & 17,0 \\
\hline 11-20x sehari & 27 & 30,7 \\
\hline 21-50x sehari & 38 & 43,2 \\
\hline$>50 x$ sehari & 7 & 8,0 \\
\hline \multicolumn{3}{|l|}{ Aktivitas Penggunaan } \\
\hline Internet browsing & 61 & 26,1 \\
\hline Sosial media & 78 & 33,3 \\
\hline Bermain games & 25 & 10,7 \\
\hline Chatting & 67 & 28,6 \\
\hline Lain-lain & 3 & 1,3 \\
\hline \multicolumn{3}{|l|}{ Pengetahuan Efek Blue Light } \\
\hline $\mathrm{Ya}$ & 55 & 62,5 \\
\hline Tidak & 33 & 37,5 \\
\hline \multicolumn{3}{|l|}{ Penggunaan Filter Blue Light } \\
\hline Ya & 33 & 37,5 \\
\hline Tidak & 55 & 62,5 \\
\hline
\end{tabular}




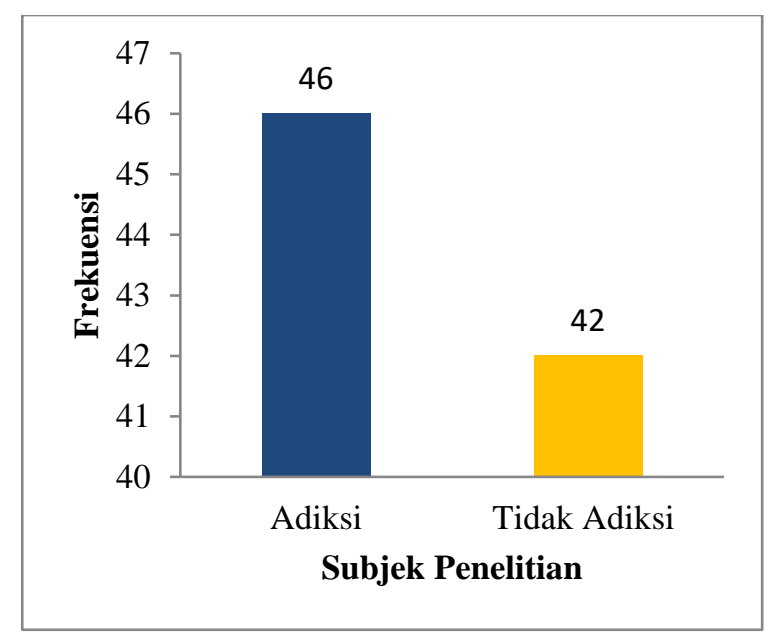

\section{Gambar 1. Subjek Penelitian Berdasarkan Tingkat Adiksi Telepon Pintar}

Hasil analisis skor kuesioner Smartphone Addiction Scale didapatkan sebaran data berdistribusi normal. Oleh karenanya digunakan nilai rata-rata skor sebagai cut-off yang membedakan antara subjek dengan adiksi dan tanpa adiksi. Didapatkan sebanyak 46 subjek $(52,3 \%)$ dengan adiksi telepon pintar (Gambar 1$)$.

Pada penelitian ini didapatkan frekuensi refleks berkedip 11 (3-44) kali/menit. Berdasarkan kuantitas air mata, sebagian besar $(76,1 \%)$ subjek mempunyai kuantitas air mata normal berdasarkan kriteria Creig dan Downie sebanyak 25 (2-35) mm selama 5 menit (Tabel 2). Pada Tabel 3 dapat dilihat hasil uji Mann-Whitney yang menunjukkan tidak ada perbedaan frekuensi refleks berkedip antara subjek tidakadiksi dengan subjek dengan adiksi telpon pintar $(\mathrm{p}=$ 0,537). Hasil uji Mann-Whitney menunjukkan terdapat perbedaan kuantitas air mata pada subjek tidak adiksi dan subjek dengan adiksi telpon pintar $(\mathrm{p}=0,011)($ Tabel 4$)$.

\section{Pembahasan}

Adiksi telepon pintar pada subjek penelitian ini terbanyak berusia 20 tahun. Hasil ini serupa dengan penelitian yang menunjukkan mahasiswa kedokteran berusia 20 tahun merupakan pengguna telepon pintar terbanyak. ${ }^{20}$ Penelitian lain menunjukkan bahwa pengguna telepon pintar terbanyak berusia antara 18-34 tahun dan banyak mahasiswa yang mengalami adiksi telepon pintar. $^{12}$

Hasil penelitian sebelumnya menunjukkan tidak ada perbedaan adiksi telepon pintar berdasarkan jenis kelamin. Laki-laki dengan adiksi sebagian besar menggunakan telepon pintarnya untuk bermain game, menonton video, dan mendengarkan musik, sedangkan perempuan menggunakannya sebagai alat telekomunikasi dan sosial media. ${ }^{20}$ Hasil serupa didapatkan pada penelitian ini yang menunjukkan sebanyak $76,1 \%$ subjek perempuan menggunakan telepon pintarnya untuk aktivitas sosial media. ${ }^{20}$

Subjek dengan adiksi menggunakan telepon pintar dengan durasi lebih dari 3 jam. ${ }^{21}$ Pada penelitian ini didapatkan sebanyak $40(45,5 \%)$ subjek menggunakan telepon pintar dengan durasi lebih dari 6 jam. Berdasarkan teori, penggunaan telepon pintar secara berlebihan berkaitan dengan beberapa masalah psikopatologi yang sesuai dengan aspek adiksi yang digambarkan dalam kuesioner Smartphone Addiction Scale. ${ }^{20}$

Tabel 3. Hubungan antara Adiksi Telepon Pintar dengan Refleks Berkedip

\begin{tabular}{lcc}
\hline $\begin{array}{l}\text { Refleks } \\
\text { Berkedip }\end{array}$ & $\begin{array}{c}\text { Median } \\
\text { (Minimun - } \\
\text { Maksimum) }\end{array}$ & P \\
\hline Subjek tidak & $12(5-44)$ & \\
adiksi & kali/menit & 0,537 \\
Subjek adiksi & $\begin{array}{l}11(3-32) \\
\text { kali/menit }\end{array}$ \\
\hline
\end{tabular}

Tabel 4. Hubungan antara Adiksi Telepon Pintar dengan Kuantitas Air Mata

\begin{tabular}{lcc}
\hline $\begin{array}{l}\text { Kuantitas Air } \\
\text { Mata }\end{array}$ & $\begin{array}{c}\text { Median (Minimun - } \\
\text { Maksimum) }\end{array}$ & P \\
\hline $\begin{array}{l}\text { Subjek tidak adiksi } \\
\text { Subjek adiksi }\end{array}$ & $21(2-35) \mathrm{mm}$ & 0,011 \\
\hline
\end{tabular}

Hasil penelitian ini didapatkan sebanyak 45 $(51,2 \%)$ subjek menggunakan telepon pintar dengan frekuensi 21-50 kali per-hari. Perilaku menggunakan atau sering melihat telepon pintar dianggap sebagai salah satu dimensi atau aspek dari adiksi telepon pintar yang digambarkan pada butir pertanyaan ke-21 kuesioner Smartphone Addiction Scale sebagai bentuk dari cyberspaceoriented relationship. ${ }^{22}$ Sebanyak 51,2\% subjek dalam penelitian ini mempunyai satu aspek dari adiksi telepon pintar, yaitu sering (21-50 kali perhari) melihat telepon pintar. Pada penelitian lain menggunakan kuesioner Smartphone Addiction Scale dengan subjek mahasiswa kedokteran didapatkan sebanyak 164 dari 192 subjek $(85,40 \%)$ mempunyai adiksi telepon pintar. $^{23}$

Adiksi telepon pintar pada mahasiswa kedokteran dapat disebabkan oleh beberapa hal 
seperti padatnya jadwal perkuliahan dan tugas yang menyebabkan mahasiswa kedokteran memiliki sedikit waktu untuk liburan atau mendapatkan hiburan sehingga menjadikan telepon pintar sebagai salah satu hiburan yang mudah didapat dan juga untuk mengakses materi pembelajaran dari internet. Selain itu, telepon pintar lebih nyaman digunakan dibandingkan laptop maupun tablet. ${ }^{21,23}$

Hasil uji Mann-Whitney menunjukkan tidak ada hubungan antara adiksi telepon pintar dengan refleks berkedip $(p=0,537)$. Pada penelitian lain didapatkan adanya penurunan refleks berkedip setelah menggunakan telepon pintar, tetapi penurunan refleks berkedip tersebut tidak signifikan. Penelitian tersebut dilakukan pada dua kelompok, yaitu kelompok menonton video dan kelompok bermain games di dalam ruangan khusus. Didapatkan sebelum menonton video didapatkan frekuensi refleks berkedip 28,3 $\pm 11,54$ $\mathrm{kali} / \mathrm{menit}$ dan sebelum main games sebanyak $30,1 \pm 12,25 \mathrm{kali} / \mathrm{menit}$. Setelah 60 menit menggunakan telepon pintar untuk menonton video refleks berkedip menurun menjadi $21,1 \pm 13,86 \mathrm{kali} / \mathrm{menit}$, sedangkan pada saat bermain games menurun menjadi 18,1 $\pm 12,09$ $\mathrm{kali} /$ menit. Menurut penelitian tersebut penurunan refleks berkedip dipengaruhi oleh atensi atau perhatian saat subjek bermain game dan menonton video. ${ }^{24}$ Pada penelitian lain yang mengukur refleks berkedip pada saat melakukan presentasi didapatkan bahwa refleks berkedip lebih dipengaruhi oleh atensi dibandingkan dengan alat presentasi yang digunakan (lembar cetak dan layar display). ${ }^{25}$

Adiksi telepon pintar merupakan salah satu masalah psikologi yang berhubungan dengan pengeluaran neurotransmiter dopamin. ${ }^{26}$ Refleks berkedip merupakan salah satu refleks yang dikendalikan oleh korteks serebral. Pengeluaran dopamin yang diproyeksikan ke korteks serebral menyebabkan terjadinya refleks berkedip secara endogen. Reflek berkedip dapat menjadi salah satu parameter pengeluaran dopamin yang diproyeksikan ke korteks serebral. ${ }^{27}$ Selain itu, refleks berkedip dapat distimulasi oleh perubahan emosional. Pada beberapa keadaan yang berhubungan dengan kognitif seperti atensi dan emosi misalnya berbicara dapat menyebabkan terjadinya perubahan refleks berkedip. Refleks berkedip normal dapat dimodifikasi oleh atensi pada saat menonton televisi atau menggunakan perangkat digital. ${ }^{6,28}$

Suatu penelitian mengukur refleks berkedip pada 6 orang subjek yang ditempatkan pada ruangan khusus. Tiga subjek memainkan games pada telepon pintar, sedangkan tiga subjek lainnya menggunakan telepon pintar dan earphone untuk menonton video. Hasil penelitian menunjukkan ada penurunan refleks berkedip yang dipengaruhi oleh atensi subjek berkaitan dengan aktivitas penggunaan telepon pintar tersebut. ${ }^{24}$ Keterbatasan penelitian ini adalah pengukuran refleks berkedip dilakukan di ruangan yang jumlah orangnya tidak dibatasi. Akibatnya atensi dan perhatian subjek dapat terganggu dan menimbulkan bias pengukuran. Diduga hal tersebut yang menyebabkan hasil penelitian ini tidak menunjukkan adanya hubungan antara adiksi telpon pintar dengan frekuensi refleks berkedip.

Hasil uji Mann-Whitney didapatkan hubungan antara adiksi telepon pintar dengan kuantitas air mata $(\mathrm{p}=0,011)$. Hasil serupa didapatkan pada penelitian yang menggunakan pretest-posttest design untuk mengukur pengaruh penggunaan telpon pintar terhadap sekresi air mata. Kuantitas air mata sebelum menggunakan telpon pintar 7,4 \pm $5,15 \mathrm{~mL}$ meningkat menjadi $13,0 \pm 8,59 \mathrm{~mL}$ setelah menggunakan telpon $\operatorname{pintar}(\mathrm{p}<0,001){ }^{24}$

Adiksi telpon pintar mengakibatkan paparan cahaya biru/blue light pada mata meningkat. Pada penelitian ini didapatkan sebanyak 55 subjek mengetahui tentang blue light, tetapi hanya 33 subjek yang menggunakan filter blue light pada telepon pintarnya. Hasil penelitian menggunakan penghitungan fototoksisitas untuk mengetahui reaksi negatif dari induksi cahaya, didapatkan bahwa filter blue light perangkat digital hanya menurunkan 2,4-9,6\% efek blue light. ${ }^{29}$

Pada awalnya efek paparan langsung blue light pada kornea mengakibatkan mata kering. Paparan tersebut akan memicu respons inflamasi berupa peningkatan interleukin-1 $\beta$ (IL-1 $\beta$ ), tumor necrosis factor- $\alpha$ (TNF- $\alpha$ ), interleukin-6 (IL-6), kemokin, serta matriks metalloproteinase (MMP)-3 dan MMP-9 yang menstimulasi korneal refleks pada cabang parasimpatis nervus fascialis. Selanjutnya terjadi stimulasi pada kelenjar lakrimal utama dan aksesoris sehingga terjadi refleks pengeluaran air mata untuk menyeimbangkan homeostasis lapisan air mata prekorneal. Kornea juga memiliki lapisan yang dapat bertindak sebagai stem cell, yaitu lapisan limbus yang dapat mengganti kerusakan kornea yang diakibatkan oleh paparan blue light. Sel pada lapisan limbus kornea (sel limbal) memiliki kemampuan untuk mempertahankan jumlah sel kornea tetap konstan dan mempertahankan kapasitasnya untuk melakukan pembaruan diri dengan meningkatkan jumlah Transient Amplifying Cells (TAC) yang 
merupakan sel progenitor yang dapat membelah secara cepat yang dapat menjadi kompartemen untuk sel limbal maupun sel kornea sehingga didapatkan kuantitas air mata yang meningkat pada subjek penelitian. Penggunaan telepon pintar oleh mahasiswa kedokteran dengan durasi lebih dari 3 jam menimbulkan sejumlah keluhan, antara lain ketegangan mata $(41,7 \%)$ dan mata berair berlebihan $(28,3 \%)^{17,18,30-34}$.

\section{Simpulan}

Berdasarkan analisis data dan pembahasan penelitian ini, didapatkan subjek berusia 20 (1823) tahun, $76,1 \%$ berjenis kelamin perempuan, 45,5\% menggunakan telpon pintar lebih dari 6 jam setiap hari, 43,2\% menggunakannya dengan frekuensi 21 - 50 kali per-hari, dan 33,3\% subjek menggunakannya untuk aktivitas sosial media. Sebanyak 37,5\% subjek mengetahui efek blue light pada mata, tetapi $62,5 \%$ subjek tidak menggunakan filter blue light pada telepon pintarnya. Hasil penelitian didapatkan 52,3\% subjek mempunyai adiksi telepon pintar dengan frekuensi refleks berkedip 11 (3 - 44) kali/menit dan kuantitas air mata 25 (2-35) mm dalam 5 menit. Tidak ada hubungan antara adiksi telepon pintar dengan refleks berkedip, tetapi ada hubungan antara adiksi telepon pintar dengan kuantitas air mata.

Subjek penelitian diharapkan lebih banyak mendapatkan informasi tentang karakteristik adiksi telpon pintar dan risikonya bagi kesehatan sehingga dapat melakukan upaya preventif atau kuratif. Subjek disarankan menggunakan filter blue light tambahan untuk melindungi mata misalnya menggunakan lapisan pelindung layar untuk telepon pintar yang memiliki kemampuan antiradiasi blue light atau menggunakan kacamata yang memiliki antiradiasi blue light.

\section{Daftar Pustaka}

1. Silverthorn DU, Johnson BR, Ober WC, Garrison CW, Silverthorn AC. Human physiology: an integrated approach. 7th ed. England: Pearson Education Inc, 2013. p. 364.

2. Kumasela GP, Saerang JSM, Rares L. Hubungan waktu penggunaan laptop dengan keluhan pengelihatan pada mahasiswa Fakutas Kedokteran Universitas Sam Ratulangi. Manado:Universitas Sam Ratulangi. J eBiomedik. 2013;1(1):291-9.
3. Sherwood L. Human physiology from cells to systems. 9th ed. Canada: Cencage Learning. 2016.

4. Stahl U, Willcox M, Stapleton F. Osmolality and tear film dynamics.Clin Exp Optom. 2012;95(1):3-11.

5. Peterson D, Hamel R. Corneal Reflex..New York: StatPearls; 2019.

6. French K, Veys J. Seeing physics in the blink of an eye. J of Vision. 2017;17(10):203.

7. Palakuru JR, Wang J, Aquavella J V. Effect of blinking on tear dynamics. Investig Ophthalmol Vis Sci. 2007;48(7):3032-7.

8. Wang MTM, Tien L, Han A, Lee JM, Kim D, Markoulli $\mathrm{M}$, et al. Impact of blinking on ocular surface and tear film parameters. Ocul Surf. 2018;16(4):424-9.

9. Kowalski K. Cell phones can be addictive. Disitasi pada tanggal 18 Mei 2020. Diunduh dari: https://www.commonlit.org/texts/watchout-cell-phones-can-be-

addictive?_cf_chl_jschl_tk__=pmd_ FcN92puPV5qcU66dCO.pgtmAu0Glsya0zR LYHYHIzD8-1632111099-0gqNtZGzNAlCjcnBszQiR

10. Golebiowski B, Long J, Harrison K, Lee A, Chidi-Egboka N, Asper L. Smartphone use and effects on tear film, blinking and binocular vision. Curr Eye Res. 2020;45(4):428-34.

11. Aljomaa SS, Mohammad MF, Albursan IS, Bakhiet SF, Abduljabbar AS. Smartphone addiction among university students in the light of some variables. Comput Human Behav. 2016;61:155-64.

12. Li X, Feng X, Xiao W, Zhou H. Loneliness and mobile phone addiction among chinese college students: the mediating roles of boredom proneness and self-control. Psychol Res Behav Manage. 2021;14;687-94.

13. Billieux J, Van Der Linden M, Rochat L. The role of impulsivity in actual and problematic Use of the mobile phone. Appl Cogn Psychol. 2008;22:877-95.

14. Kwon M, Kim DJ, Cho H, Yang S. The smartphone addiction scale:development and validation of a short version for adolescents. PLoS One. 2013;8(12):1-7.

15. Kim DJ, Lim C-Y, Gu N, Park CY. Visual fatigue induced by viewing a tablet computer with a high-resolution display. Korean J Ophthalmol. 2017;31(5):388.

16. Jaiswal S, Asper L, Long J, Lee A, Harrison K, Golebiowski B. Ocular and visual discomfort associated with smartphones, tablets and 
computers: what we do and do not know. Clin Exp Optom. 2019;102(5):463-77.

17. Arjmandi N, Mortazavi G, Zarei S, Faraz M, Mortazavi SAR. Can light emitted from smartphone screens and taking selfies cause premature aging and wrinkles? J Biomed Phys Eng. 2018;8(4):447-52.

18. Choi JH, Li Y, Kim SH, Jin R, Kim YH, Choi $\mathrm{W}$, et al. The influences of smartphone use on the status of the tear film and ocular surface. PLoS One. 2018;13(10):1-16.

19. Rizky, MR, Nawangwulan S. Metodologi penelitian kesehatan. Sidoarjo: Indomedia Pustaka; 2018.

20. Chen B, Liu F, Ding S, Ying X, Wang L, Wen Y. Gender differences in factors associated with smartphone addiction: a cross-sectional study among medical college students. BMC Psychiatry. 2017;17(1):1-9.

21. Alhazmi AA, Alzahrani SH, Baig M, Salawati EM, Alkatheri A. Prevalence and factors associated with smartphone addiction among medical students at King Abdulaziz University, Jeddah. Pakistan J Med Sci. 2018;34(4):984-8.

22. Gutiérrez JDS, de Fonseca FR, Rubio G. Cellphone addiction: a review. Front Psychiatry. 2016;7.

23. Sethuraman AR, Rao S, Charlette L, Thatkar PV, Vincent V. Smartphone addiction among medical college students in the Andaman and Nicobar Islands. Int J Community Med Public Heal. 2018;5(10):4273-7.

24. Park JS, Choi MJ, Ma JE, Moon JH, Moon HJ. Influence of cellular phone videos and games on dry eye syndrome in university students. $\mathbf{J}$ Korean Acad Community Heal Nurs. 2014;25(1):12.

25. Rosenfield M, Jahan S, Nunez K, Chan K. Cognitive demand, digital screens and blink rate. Comput Human Behav. 2015;51:403-6.

26. Solinas M, Belujon P, Fernagut PO, Jaber M, Thiriet N. Dopamine and addiction: what have we learned from 40 years of research. Journal of Neural Transmission. 2019;126:481-516.

27. Jongkees BJ, Colzato LS. Spontaneous eye blink rate as predictor of dopamine-related cognitive function-A review. Neurosci Biobehav Rev. 2016;71:58-82.

28. Paprocki R, Lenskiy A. What does eye-blink rate variability dynamics tell us about cognitive performance? Front Hum Neurosci. 2017;11:1-9.
29. Leung TW, Li RW, Kee C. Blue-light filtering spectacle lenses: Optical and clinical performances. PLoS One. 2017;12(1):1-15.

30. Kumar BS. A study to evaluate the knowledge regarding computer vision syndrome among medical students. Biomed Pharmacol J. 2020;13(1):469-73.

31. Zhao ZC, Zhou Y, Tan G, Li J. Research progress about the effect and prevention of blue light on eyes. Int $\mathrm{J}$ Ophthalmol. 2018;11(12):1999-2003.

32. Sacchetti M, Rama P, Bruscolini A, Lambiase A. Limbal stem cell transplantation: Clinical results limits, and perspectives. Stem Cells Int. 2018;8086269.

33. Pflugfelder SC, de Paiva CS. The pathophysiology of dry eye disease: What we know and future directions for research. Ophthalmology. 2017;124(11):S4-13.

34. Tosini G, Ferguson I, Tsubota K. Effects of blue light on the circadian system and eye physiology. Mol Vis. 2016;22:61-72. 